Oral presentation

Open Access

\title{
Structural insights into sGC
}

Focco van den Akker*1, Xiaolei Ma², Faye Martin1, Priyaranjan Pattanaik², Pius Padayatti ${ }^{4}$, Matthew Warman ${ }^{5}$ and Annie Beuve ${ }^{6}$

Address: ${ }^{1}$ Department of Biochemistry/RT500, Case Western Reserve University, Cleveland, OH, 44106, USA, ${ }^{2}$ Genentech, San Francisco, CA, USA, ${ }^{3}$ Syngene, Bangalore, India, ${ }^{4}$ Polgenix, Cleveland, OH, USA, ${ }^{5}$ Harvard Medical School, Boston, MA, USA and ${ }^{6}$ UMNDJ, Newark, NJ, USA

Email: Focco van den Akker* - focco.vandenakker@case.edu

* Corresponding author

from 4th International Conference of cGMP Generators, Effectors and Therapeutic Implications

Regensburg, Germany. 19-21 June 2009

Published: II August 2009

BMC Pharmacology 2009, 9(Suppl I):S42 doi:I0.II86/I47I-22I0-9-SI-S42

This abstract is available from: http://www.biomedcentral.com/I47I-22I0/9/SI/S42

(c) 2009 Akker et al; licensee BioMed Central Ltd.

The membrane and soluble guanylyl cyclases (sGCs) are key families of enzymes that produce the second messenger cGMP. Although both families recognize different ligands and have therefore different $\mathrm{N}$-terminal input domains, they do have similar C-terminal output domains containing a coiled-coil domain and a guanylyl cyclase catalytic domain. We present here our latest structure-function studies on both the sGC and membrane guanylyl cyclases in an effort to enhance our molecular understanding of these receptors to delineate their similarities and differences. Our studies include a new $2.15 \AA$ crystal structure of part of sGC and mutagenesis studies of these families of guanylyl cyclases thereby providing new insights into the structure, activation, and regulation of these receptors. 